\title{
Bottom-up gamma: the pedunculopontine nucleus and reticular activating system
}

\author{
Garcia-Rill E*, D’Onofrio S, and Mahaffey $S$ \\ Center for Translational Neuroscience, University of Arkansas for Medical Sciences, USA
}

\begin{abstract}
Gamma rhythms have been proposed to promote the feed forward or "bottom-up" flow of information from lower to higher regions in the brain during perception. On the other hand, beta rhythms have been proposed to represent feedback or "top-down" influence from higher regions to lower. The pedunculopontine nucleus (PPN) has been implicated in sleep-wake control and arousal, and is part of the reticular activating system (RAS). This review describes the properties of the cells in this nucleus. These properties are unique, and perhaps it is the particular characteristics of these cells that allow the PPN to be involved in a host of functions and disorders. The fact that all PPN neurons fire maximally at gamma band frequency regardless of electrophysiological or transmitter type, make this an unusual cell group. In other regions, for example in the cortex, cells with such a property represent only a sub-population. More importantly, the fact that this cell group's functions are related to the capacity to generate coherent activity at a preferred natural frequency, gamma band, speaks volumes about how the PPN functions. We propose that "bottom-up" gamma band influence arises in the RAS and contributes to the build-up of the background of activity necessary for preconscious awareness and gamma activity at cortical levels.
\end{abstract}

\section{Introduction}

Bottom-up or feed forward brain processes depend on sensory events as stimuli activate lower brain centers and the information rises to succeeding higher centers to promote perception. Top-down or feedback processing refers to the influence imposed by higher centers on the perception of and attention to incoming stimuli. Recent studies suggest that feed forward and feedback signaling use different frequency channels, specifically gamma and beta frequencies, respectively [1]. This review is concerned with questions about bottomup processes, specifically, where does the gamma activity arise? Is the gamma band activity generated only at the level of the cortex, or does it arise from lower centers to interact with ongoing cortical activity? What mechanisms generate activity at such frequencies? Can synaptic circuits maintain such frequencies for any length of time, or are there other mechanisms involved? Which lower centers generate gamma band activity, and is it coherent with cortical gamma band activity?

\section{Role of gamma band activity}

Gamma oscillations appear to participate in sensory perception, problem solving, and memory [2-7], and coherence at these frequencies may occur at cortical or thalamocortical levels $[8,9]$. Indeed, synchronous gamma band activation among thalamocortical networks [10], and in other neuronal groups is thought to contribute to the merger, or "binding", of information originating from separate regions [11]. On the other hand, gamma oscillation deficits have been suggested as a pathophysiologic feature of diseases like schizophrenia and Alzheimer's disease [12-15].

Gamma oscillations are thought to emerge from the dynamic interaction between intrinsic neuronal and synaptic properties of thalamocortical networks [12]. That is, synaptic connections alone may not be able to maintain firing at gamma frequencies $(\sim 30-90 \mathrm{~Hz})$, so that intrinsic membrane properties also appear essential to the maintenance of gamma band activity. For example, flicker fusion of visual inputs demonstrates that cortical circuits cannot "follow" individual visual stimuli presented at rates above $35 \mathrm{~Hz}$ or so. That is, cortical circuits appear incapable of reliably firing at gamma frequencies for any length of time. Therefore, the ability of cells with intrinsic membrane properties, coupled with synaptic interactions, is what allows the circuit as a whole to fire at a preferred frequency, and is essential to maintaining frequencies in the gamma range. The neuronal mechanisms behind such activity include the presence of inhibitory cortical interneurons with intrinsic membrane potential oscillatory activity in the gamma range $[8,12,16]$, many of which are electrically coupled [17], as well as of fast rhythmic bursting pyramidal neurons [18]. At the thalamic level, thalamocortical excitatory neurons have intrinsic properties needed to generate subthreshold gamma band membrane potential oscillations [19].

While cortical interneurons can generate membrane potential gamma oscillations through the activation of voltage-dependent, persistent sodium channels [8], in thalamocortical neurons, the main mechanism responsible for gamma band activity involves high threshold $\mathrm{P} / \mathrm{Q}$-type voltage-gated calcium channels located in the dendrites [19]. Moreover, the same intrinsic properties mediating gamma band oscillations are present in the thalamus of several vertebrate species, indicating considerable evolutionary conservation [20]. It thus appears that at least two types of intrinsic membrane properties are essential

Correspondence to: E. Garcia-Rill, $\mathrm{PhD}$, Director, Center for Translational Neuroscience, Department of Neurobiology and Developmental Sciences, University of Arkansas for Medical Sciences, Slot 847, 4301 West Markham St., Little Rock, AR 72205, USA, Tel: 501-686-5167, Fax: 501-526-7928, E-mail: GarciaRillEdgar@uams.edu

Key words: arousal, beta oscillations, Ca2 $2^{+}$channels, gamma oscillations

Received: June 20, 2016; Accepted: September 28, 2016; Published: October 07,2016 
for generating gamma band activity, sodium-dependent subthreshold oscillations and voltage-dependent high threshold calcium channels.

Voltage-gated calcium channel involvement in gamma band generation is particularly important. Indeed, calcium channels are known to play a pivotal role in determining intrinsic properties and synaptic transmission throughout the central nervous system [2125]. P/Q-type channels (also known as $\mathrm{Ca}_{\mathrm{v}} 2.1$ channels) are present widely in the brain [4,25-27]. N-type calcium channels are found in the rat auditory brainstem, are restricted to the early postnatal period, and are replaced by P/Q-type channels later in development $[28,29]$. Importantly, P/Q-type mutant mice have deficient gamma band activity in the EEG, abnormal sleep-wake states, ataxia, are prone to seizures (low frequency synchrony), and die by 3 weeks of age [30]. These findings suggest that both the cortex and the thalamus may be capable of generating gamma band activity, and they do so via subpopulations of cells with sodium-dependent and/or calcium channeldependent mechanisms. But do other regions of the brain also generate such activity?

\section{Subcortical gamma band activity}

Both the hippocampus and cerebellum have the intrinsic and synaptic properties necessary to generate gamma band oscillatory activity. Hippocampal oscillatory activity in the gamma range (30-90 $\mathrm{Hz}$ ) has been extensively described to be functional associated with entorhinal cortex afferents [31]. Interestingly, neurons located in the entorhinal cortex can also oscillate at gamma band frequencies, suggesting a key role for such afferents in maintaining hippocampal gamma oscillations [32]. Recently, gamma band activity in the CA1 area was divided into high $(>65 \mathrm{~Hz})$ and low $(\sim 25-60 \mathrm{~Hz})$ gamma frequency components that differentially couple CA1 and CA3 subfields, respectively [33]. Such differences have been proposed to "bind" CA1 high gamma oscillations with very high frequency activity from entorhinal cortex in charge of providing information about object and place recognition in rodents [34], whereas CA1 low gamma oscillations would be locked to the slower frequencies present in the CA3 area in charge of memory storage [33,35]. This suggests the use of different frequency bands for separate functions.

Similarly, a peak in gamma band power has been described in the Purkinje cell layer around the apex of the cerebellar lobule, and to a lower extent in distal white matter [36,37]. Moreover, the cerebellar activity is coherent with that of the cortex and thalamus. Corticocerebellar coherence at gamma frequencies is evident in monkeys during performance of a manual precision grip task [38], and cerebellothalamic activity is synchronized with neocortical activity at gamma frequencies [39]. Finally, it has been proposed that both cerebellar and thalamocortical networks might oscillate at the same frequencies to enable information exchange among these brain areas [37]. It was found that gamma band activity in the motor cortex lags behind coherent activity in basal ganglia structures $[40,41]$. This led to the suggestion that motor cortex gamma synchronization reflects a momentary arousal-related event for enabling the initiation of movement [42-44]. That is, structures such as the RAS and thalamus may play an early permissive role in the control of movement. Thus, there are several other regions generating gamma band activity besides the cortex and thalamus, including the hippocampus, cerebellum, basal ganglia, and importantly, the reticular activating system (RAS).

\section{Waking and REM sleep}

During waking and rapid eye movement (REM) sleep, the
EEG shows low amplitude, high frequency activity at beta/gamma frequencies $(\sim 20-30 / 30-90 \mathrm{~Hz})$ [45]. The pedunculopontine nucleus (PPN) is most active during waking and REM sleep [46]. The PPN is the arm of the RAS that modulates ascending projections through the thalamus (modulating arousal) and descending projections through the pons and medulla (modulating posture and locomotion) [46], and is composed of different populations of cholinergic, glutamatergic, and GABAergic neurons [47]. Extracellular recordings of PPN neurons in vivo identified six categories of thalamic projecting PPN cells distinguished by their firing properties relative to ponto-geniculooccipital wave generation [48]. Some of these neurons had low rates of spontaneous firing $(<10 \mathrm{~Hz})$, but most had high rates of tonic firing in the beta/gamma range $(20-80 \mathrm{~Hz})$. It has been shown that PPN neurons exhibit beta/gamma frequencies in vivo during active waking and REM sleep, but not during slow wave sleep [48-53]. Similarly, the presence of gamma band activity has been confirmed in the cortical EEG of the cat in vivo when the animal is active [48]; and in the region of the PPN in humans during stepping, but not at rest [54]. A recent study showed that PPN neurons fired at low frequencies $\sim 10 \mathrm{~Hz}$ at rest, but the same neurons increased firing to gamma band frequencies when the animal woke up, or when the animal began walking on a treadmill [55]. That is, the same cells were involved in both arousal and motor control. Thus, there is ample evidence for gamma band activity during active waking and movement in the PPN in vitro, in vivo, and across species, including man.

\section{Mechanism behind PPN gamma activity}

A number of recent publications have described the mechanisms behind gamma band activity in the PPN [56-61], and will not be reiterated. Briefly, these oscillations are mediated by voltage-dependent, high threshold $\mathrm{N}$ - and P/Q-type calcium channels that are present in every PPN neuron, regardless of cell or transmitter type. These channels are distributed along the dendrites of PPN cells [62]. Presumably, afferent input traveling through "specific" sensory pathways diverges to activate "non-specific" reticular pathways to activate PPN dendrites. However, gamma band activity during waking has different mechanisms than gamma band activity during REM sleep. Injections of glutamate into the PPN increased waking and REM sleep [63], while injections of the glutamatergic receptor agonist N-methyl-D-aspartic acid (NMDA) increased only waking [64], and injections of the glutamatergic receptor agonist kainic acid (KA) increased only REM sleep [65]. Intracellularly, protein kinase $\mathrm{C}(\mathrm{PKC})$, which modulates $\mathrm{KA}$ receptors, enhances $\mathrm{N}$-type channel activity and has no effect on P/Q-type channel function [66], but CaMKII, which modulates NMDA receptors, was shown to modulate P/Q-type channel function [67].

That is, the two calcium channel subtypes are modulated by different intracellular pathways, $\mathrm{N}$-type by the cAMP/PK pathway, and $\mathrm{P} / \mathrm{Q}$-type via the CaMKII pathway. Moreover, there are three cell types in the PPN, those bearing only N-type calcium channels, those with both N- and P/Q-type, and those with only P/Q-type calcium channels $[68,69]$. The implications from all of these results is that, a) there is a "waking" pathway mediated by CaMKII and P/Q-type channels and a "REM sleep" pathway mediated by cAMP/PK and N-type channels, and b) different PPN cells fire during waking (those with N+P/Q and only $\mathrm{P} / \mathrm{Q}$-type) vs REM sleep (those with $\mathrm{N}+\mathrm{P} / \mathrm{Q}$ and only N-type).

\section{Ascending projections}

The main ascending output of the PPN is to the intralaminar thalamus (ILT), specifically, the parafascicular nucleus (Pf). The ILT and Pf receive projections from the cholinergic PPN nuclei with both 
symmetrical and asymmetrical terminals [70-73]. In turn, Pf neurons send widespread projections to the cortex, striatum, subthalamic nucleus, and substantia nigra $[74,75]$. The Pf is thought to be involved in maintaining consciousness and selective attention in primates [76,77]. We found that all Pf cells recorded manifested P/Q-type calcium channels and fired maximally at gamma band frequency [78]. Moreover, these channels were distributed along the dendrites of the neurons, just as in PPN [79].

These findings provided novel insights into the function of the Pf, demonstrating that it generates gamma band oscillatory activity in the presence of sufficient excitation from the PPN. We suggest that, rather than participating in the temporal binding of sensory events, gamma band activity generated in the PPN and relayed to the Pf may help stabilize coherence related to arousal, providing a stable activation state during waking, and relay such activation to the cortex, which thus participates in "non-specific" thalamocortical processing. Most of our thoughts and actions are driven by preconscious processes. We speculate that continuous sensory input will induce gamma band activity in the PPN that is relayed to the Pf to participate in the processes of preconscious awareness, and provide the essential stream of information for the formulation of many of our actions [56-59,61]. Figure 1 shows a wiring diagram of the projections and mechanisms described.

\section{Bottom-up gamma}

The original description of the RAS specifically suggested that it participates in tonic or continuous arousal [80], and lesions of this region were found to eliminate tonic arousal [81]. This raises the question of how a circuit can maintain such rapid, recurrent activation. Expecting a circuit of 5 or 10 synapses to reliably relay $20-60 \mathrm{~Hz}$ cycling without failing is unrealistic. Without the intrinsic properties afforded by rapidly oscillating channels, such as those described recently for the PPN and Pf, beta/gamma band activity could not be maintained. The combination of channels capable of fast oscillations and of circuitry that involves activating these channels probably are both required for

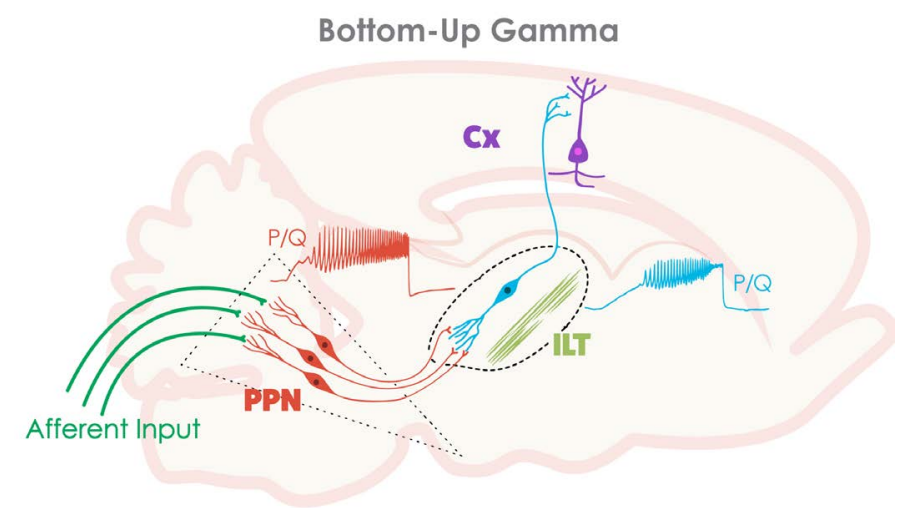

Figure 1. Wiring diagram and mechanisms behind bottom-up gamma band activity. Afferent input (green lines) that originates from collateral activation of the RAS by sensory systems activates the dendrites of PPN neurons (red) in the posterior midbrain. The presence of inputs to dendritic $\mathrm{P} / \mathrm{Q}$ - and N-type calcium channels set off oscillations at gamma band that influence firing frequency. The output of the PPN ascends to the intralaminar thalamus (ILT), especially the parafascicular nucleus, activating its dendrites to oscillate at gamma frequency via high threshold calcium channels (blue). These cells in turn project to the cortex, particularly to upper cortical layers where the non-specific thalamic inputs terminate, to activate cortical neurons (purple). Once cortical, hippocampal, basal ganglia, and cerebellar cells are activated, the generation and maintenance of gamma band activity in the brain can more easily be maintained through synaptic and intrinsic membrane properties. the maintenance of gamma band activity $[8,24,46,56-60]$. The PPN and Pf, in which every cell manifests gamma band activity, then becomes a gamma-making machine. We speculate that it is the continued activation of the RAS during waking that allows the maintenance of the background of gamma activity necessary to support the state capable of reliably assessing the world around us on a continuous basispreconscious awareness.

\section{Acknowledgments}

This work was supported by NIH award R01 NS020246, and by core facilities of the Center for Translational Neuroscience supported by NIH award P20 GM103425 and P30 GM110702 to Dr. Garcia-Rill.

\section{References}

1. Bastos AM, Vezoli J, Bosman CA, Schoffelen JM, Oostenveld R, et al. (2015) Visual areas exert feedforward and feedback through distinct frequency channels. Neuron 85 : 390-40. [Crossref]

2. Eckhorn R, Bauer R, Jordan W, Brosch M, Kruse W, et al. (1988) Coherent oscillations a mechanism of feature linking in the visual cortex? Multiple electrode and correlation analyses in the cat. Biol Cybern 60: 121-130. [Crossref]

3. Gray CM, Singer W (1989) Stimulus-specific neuronal oscillations in orientation columns of cat visual cortex. Proc Natl Acad Sci U S A 86: 1698-1702. [Crossref]

4. Jones EG (2007) Calcium channels in higher-level brain function. Proc Natl Acad Sci US A104: 17903-17904. [Crossref]

5. Phillips S, Takeda Y (2009) Greater frontal-parietal synchrony at low gammaband frequencies for inefficient than efficient visual search in human EEG. Int $J$ Psychophysiol 73: 350-354. [Crossref]

6. Palva S, Monto S, Palva JM (2010) Graph properties of synchronized cortical networks during visual working memory maintenance. Neuroimage 49: 3257-3268. [Crossref]

7. Voss U, Holzmann R, Tuin I, Hobson JA (2009) Lucid dreaming: a state of consciousness with features of both waking and non-lucid dreaming. Sleep 32: 1191-1200. [Crossref]

8. Llinás RR, Grace AA, Yarom Y (1991) In vitro neurons in mammalian cortical layer 4 exhibit intrinsic oscillatory activity in the 10 - to $50-\mathrm{Hz}$ frequency range. Proc Natl Acad Sci U S A 88: 897-901. [Crossref]

9. Singer W (1993) Synchronization of cortical activity and its putative role in information processing and learning. Annu Rev Physiol 55: 349-374. [Crossref]

10. Llinas RR, Leznik E, Urbano FJ (2002) Temporal binding via cortical coincidence detection of specific and nonspecific thalamocortical inputs: a voltage-dependent dyeimaging study in mouse brain slices. Proc Natl Acad Sci USA 99: 449-454. [Crossref]

11. Llinás RR, Paré D (1991)Of dreaming and wakefulness. Neurosci 44: 521-535. [Crossref]

12. Steriade M, Llinás RR (1988) The functional states of the thalamus and the associated neuronal interplay. Physiol Rev 68: 649-742. [Crossref]

13. Ribary U, Ioannides AA, Singh KD, Hasson R, Bolton JP, et al. (1991) Magnetic field tomography of coherent thalamocortical $40-\mathrm{Hz}$ oscillations in humans. Proc Natl Acad Sci U S A 88: 11037-11041. [Crossref]

14. Stam CJ, van Cappellen van Walsum AM, Pijnenburg YA, Berendse HW, de Munck JC, et al. (2002) Generalized synchronization of MEG recordings in Alzheimer's Disease: evidence for involvement of the gamma band. J Clin Neurophysiol 19: 562574. [Crossref]

15. Uhlhaas PJ, Singer W (2013) High-frequency oscillations and the neurobiology of schizophrenia. Dialogues Clin Neurosci 15: 301-313. [Crossref]

16. Steriade M (1999) "Cellular substrates of oscillations in corticothalamic systems during states of vigilance." In Handbook of Behavioral State Control. Cellular and molecular mechanisms, ed. Lydic, R. \&Baghdoyan, H.A. (CRC Press, New York), pp. 327-347.

17. Gibson JR, Beierlein M, Connors BW (1999) Two networks of electrically coupled inhibitory neurons in neocortex. Nature 402: 75-79. [Crossref]

18. Cunningham MO, Whittington MA, Bibbig A, Roopun A, LeBeau FE, et al. (2004) A role for fast rhythmic bursting neurons in cortical gamma oscillations in vitro. Proc Natl Acad Sci US A 101: 7152-7157. [Crossref]

19. Pedroarena C, Llinás R (1997) Dendritic calcium conductances generate high- 
frequency oscillation in thalamocortical neurons. Proc Natl Acad Sci U S A94: 724728. [Crossref]

20. Llinás RR, Steriade M (2006) Bursting of thalamic neurons and states of vigilance. $J$ Neurophysiol 95: 3297-3308. [Crossref]

21. Katz B, Miledi R (1965) The effect of calcium on acetylcholine release from motor nerve terminals. Proc R SocLond B BiolSci161: 496-503. [Crossref]

22. Llinás R, Hess R (1976) Tetrodotoxin-resistant dendritic spikes in avian Purkinje cells. Proc Natl AcadSci U S A73: 2520-2523. [Crossref]

23. Catterall WA (1998) Structure and function of neuronal Ca2+ channels and their role in neurotransmitter release. Cell Calcium 24: 307-323. [Crossref]

24. Llinas RR (1988)The intrinsic electrophysiological properties of mammalian neurons: insights into central nervous system function. Science 242: 1654-1664. [Crossref]

25. Llinás RR, Choi S, Urbano FJ, Shin HS (2007) Gamma-band deficiency and abnormal thalamocortical activity in P/Q-type channel mutant mice. Proc Natl Acad Sci U S A 104: 17819-17824. [Crossref]

26. Hillman D, Chen S, Aung TT, Cherksey B, Sugimori M, et al. (1991) Localization of P-type calcium channels in the central nervous system. Proc Natl Acad Sci U S A 88: 7076-7080. [Crossref]

27. Uchitel OD, Protti DA, Sanchez V, Cherksey BD, Sugimori M, et al. (1992) P-type voltage-dependent calcium channel mediates presynaptic calcium influx and transmitter release in mammalian synapses. Proc Natl Acad Sci U S A 89: 3330-3333. [Crossref]

28. Iwasaki S, Takahashi T (1998) Developmental changes in calcium channel types mediating synaptic transmission in rat auditory brainstem. $J$ Physiol 509: 419-423. [Crossref]

29. Westenbroek RE, Hell JW, Warner C, Dubel SJ, Snutch TP, et al. (1992) Biochemical properties and subcellular distribution of an $\mathrm{N}$-type calcium channel alpha 1 subunit. Neuron 9: 1099-1115. [Crossref]

30. Llinás RR, Choi S, Urbano FJ, Shin HS (2007) Gamma-band deficiency and abnormal thalamocortical activity in P/Q-type channel mutant mice. Proc Natl Acad Sci U S A 104: 17819-17824. [Crossref]

31. Charpak S, Paré D, Llinás R (1995) The entorhinal cortex entrains fast CA1 hippocampal oscillations in the anaesthetized guinea-pig: role of the monosynaptic component of the perforant path. Eur J Neurosci 7: 1548-1557. [Crossref]

32. Chrobak JJ, Buzsáki G (1998) Gamma oscillations in the entorhinal cortex of the freely behaving rat. $J$ Neurosci 18: 388-398. [Crossref]

33. Colgin LL, Denninger T, Fyhn M, Hafting T, Bonnevie T, et al. (2009) Frequency of gamma oscillations routes flow of information in the hippocampus. Nature 462: 353 357. [Crossref]

34. Bussey TJ, Muir JL, Aggleton JP (1999) Functionally dissociating aspects of event memory: the effects of combined perirhinal and postrhinal cortex lesions on object and place memory in the rat. J Neurosci 19: 495-502. [Crossref]

35. Colgin LL, Moser EI (2010) Gamma oscillations in the hippocampus. Physiology (Bethesda) 25: 319-329. [Crossref]

36. Lang EJ, Sugihara I, Llinás R (2006) Olivocerebellar modulation of motor cortex ability to generate vibrissal movements in rat. J Physiol 571: 101-120. [Crossref]

37. Middleton SJ, Racca C, Cunningham MO, Traub RD, Monyer H, et al. (2008) Highfrequency network oscillations in cerebellar cortex. Neuron 58: 763-774. [Crossref]

38. Soteropoulos DS, Baker SN (2006) Cortico-cerebellar coherence during a precision grip task in the monkey. J Neurophysiol 95: 1194-1206. [Crossref]

39. Timofeev I, Steriade M (1997) Fast (mainly 30-100 Hz) oscillations in the cat cerebellothalamic pathway and their synchronization with cortical potentials. J Physiol 504 : 153-168. [Crossref]

40. Lalo E, Thobois S, Sharott A, Polo G, Mertens P, et al. (2008) Patterns of bidirectional communication between cortex and basal ganglia during movement in patients with Parkinson disease. J Neurosci 28: 3008-3016. [Crossref]

41. Trottenberg T, Fogelson N, Kühn AA, Kivi A, Kupsch A, et al. (2006) Subthalamic gamma activity in patients with Parkinson's disease. ExpNeurol200: 56-65. [Crossref]

42. Brucke C, Huebl J, Kempf F, Krauss JK, Yarrow K, et al. (2008)Pallidal gamma activity is correlated to movement amplitude in patients with dystonia. Clin Neurophysiol 119: (S1)49.

43. Cheyne D, Ferrari P (2013) MEG studies of motor cortex gamma oscillations: evidence for a gamma "fingerprint" in the brain? Front Hum Neurosci 7: 575. [Crossref]
44. Jenkinson N, Kühn AA, Brown P (2013) $\hat{\mathrm{I}}^{3}$ oscillations in the human basal ganglia. Exp Neurol 245: 72-76. [Crossref]

45. Buzsáki G, Draguhn A (2004) Neuronal oscillations in cortical networks. Science 304 1926-1929. [Crossref]

46. Garcia-Rill E (2015) Waking and the Reticular Activating System. Academic Press, New York, USA pp. 330.

47. Wang HL, Morales M (2009) Pedunculopontine and laterodorsal tegmental nucle contain distinct populations of cholinergic, glutamatergic and GABAergic neurons in the rat. Eur J Neurosci 29: 340-358. [Crossref]

48. Steriade M, Paré D, Datta S, Oakson G, CurróDossi R (1990) Different cellular types in mesopontine cholinergic nuclei related to ponto-geniculo-occipital waves. J Neurosci 10: 2560-2579. [Crossref]

49. Sakai K, el Mansari M, Jouvet M (1990) Inhibition by carbachol microinjections of presumptive cholinergic PGO-on neurons in freely moving cats. Brain Res 527: 213 223. [Crossref]

50. Kayama Y, Ohta M, Jodo E (1992) Firing of 'possibly' cholinergic neurons in the rat laterodorsal tegmental nucleus during sleep and wakefulness. Brain Res 569: 210-220. [Crossref]

51. Datta S, Siwek DF (2002) Single cell activity patterns of pedunculopontine tegmentum neurons across the sleep-wake cycle in the freely moving rats. J Neurosci Res 70: 611621. [Crossref]

52. Datta S, Siwek DF, Stack EC (2009) Identification of cholinergic and non-cholinergic neurons in the pons expressing phosphorylated cyclic adenosine monophosphate response element-binding protein as a function of rapid eye movement sleep. Neurosci 163: 397-414. [Crossref]

53. Boucetta S, Cisse Y, Mainville L, Morales M, Jones BE (2014) Discharge profiles across the sleep-waking cycle of identified cholinergic, gabaergic, and glutamatergic neurons in the pontomesencephalic tegmentum of the rat. $J$ Neurosci 34: 4708-4727. [Crossref]

54. Fraix V, Bastin J, David O, Goetz L, Ferraye M, et al. (2013) Pedunculopontine nucleus area oscillations during stance, stepping and freezing in Parkinson's disease. PLoS One 8: e83919. [Crossref]

55. Goetz L, Piallat B, Bhattacharjee M, et al. (2016) The primate pedunculopontine nucleus region: towards a dual role in locomotion and waking state. J Neural Transm (Vienna) 123: 667-678. [Crossref]

56. Garcia-Rill E, Kezunovic N, Hyde J, Simon C, Beck P, et al. (2013) Coherence and frequency in the reticular activating system (RAS). Sleep Med Rev 17: 227-238. [Crossref]

57. Garcia-Rill E, Kezunovic N, D’Onofrio S, Luster B, Hyde J, et al. (2014) Gamma band activity in the RAS-intracellular mechanisms. Exp Brain Res 232: 1509-1522. [Crossref]

58. Garcia-Rill E, Luster B2, D’Onofrio S2, Mahaffey S2, Bisagno V3, et al. (2016) Implications of gamma band activity in the pedunculopontine nucleus. J Neural Transm (Vienna) 123: 655-665. [Crossref]

59. Garcia-Rill E, D’Onofrio S, Luster B, Mahaffey S, Urbano FJ, et al. (2016) The 10 Hz Frequency: A Fulcrum For Transitional Brain States. Transl Brain Rhythm 1: 7-13. [Crossref]

60. Kezunovic N, Urbano FJ, Simon C, Hyde J, Smith K, et al. (2011) Mechanism behind gamma band activity in the pedunculopontine nucleus. Eur J Neurosci 34: 404-415. [Crossref]

61. Urbano FJ, D’Onofrio SM, Luster BR, Beck PB, Hyde JR, et al. (2014) Pedunculopontine Nucleus Gamma Band Activity-Preconscious Awareness, Waking, and REM Sleep. Front Neurol 5: 210. [Crossref]

62. Hyde J, Kezunovic N, Urbano FJ, Garcia-Rill E (2013) Spatiotemporal properties of high-speed calcium oscillations in the pedunculopontine nucleus. J Appl Physiol (1985) 115: 1402-1414. [Crossref]

63. Datta S, Spoley EE, Patterson EH (2001) Microinjection of glutamate into the pedunculopontine tegmentum induces REM sleep and wakefulness in the rat. $\mathrm{Am} J$ Physiol RegulIntegr Comp Physiol 280: R752-759. [Crossref]

64. Datta S (2002) Evidence that REM sleep is controlled by the activation of brain stem pedunculopontine tegmental kainate receptor. J Neurophysiol87: 1790-1798. [Crossref]

65. Datta S, Patterson EH, Spoley EE (2001) Excitation of the pedunculopontine tegmenta NMDA receptors induces wakefulness and cortical activation in the rat. $J$ Neurosci Res 66: 109-116. [Crossref] 
66. Stea A, Soong TW, Snutch TP (1995) Determinants of PKC-dependent modulation of a family of neuronal calcium channels. Neuron 15: 929-940. [Crossref]

67. Jiang X, Lautermilch NJ, Watari H, Westenbroek RE, Scheuer T, et al. (2008) Modulation of CaV2.1 channels by $\mathrm{Ca} 2+/$ calmodulin-dependent protein kinase II bound to the C-terminal domain. Proc Natl Acad Sci U S A 105: 341-346. [Crossref]

68. Luster B, D’Onofrio S, Urbano F, Garcia-Rill E (2015) High-threshold Ca2+ channels behind gamma band activity in the pedunculopontine nucleus (PPN). Physiol Rep 3. [Crossref]

69. Luster BR, Urbano FJ, Garcia-Rill E (2016) Intracellular mechanisms modulating gamma band activity in the pedunculopontine nucleus (PPN). Physiol Rep 4. [Crossref]

70. Capozzo A, Florio T, Cellini R, Moriconi U, Scarnati E (2003) The pedunculopontine nucleus projection to the parafascicular nucleus of the thalamus: an electrophysiological investigation in the rat. J Neural Transm (Vienna) 110: 733-747. [Crossref]

71. Erro E, Lanciego JL, and Gimenez-Amaya JM (1999) Relationships between thalamostriatal neurons and pedunculopontine projections to the thalamus: a neuroanatomical tract-tracing study in the rat. Exp Brain Res 127: 162-170. [Crossref]

72. Kha HT, Finkelstein DI, Pow DV, Lawrence AJ, Horne MK (2000) Study of projections from the entopeduncular nucleus to the thalamus of the rat. J Comp Neurol 426: 366377. [Crossref]

73. Kobayashi S, Nakamura Y (2003) Synaptic organization of the rat parafascicular nucleus, with special reference to its afferents from the superior colliculus and the pedunculopontine tegmental nucleus. Brain Res 980: 80-91. [Crossref]

74. Herrero MT, Barcia C, Navarro JM (2002) Functional anatomy of thalamus and basal ganglia. Childs Nerv Syst 18: 386-404. [Crossref]

75. Van der WerfYD, Witter MP, Groenewegen HJ (2002) Theintralaminar and midline nuclei of the thalamus. Anatomical and functional evidence for participation in processes of arousal and awareness. Brain Res Brain Res Rev 39: 107-140. [Crossref]

76. Minamimoto T, Kimura M (2002) Participation of the thalamic CM-Pf complex in attentional orienting. J Neurophysiol 87: 3090-3101. [Crossref]

77. Raeva SN (2006) The role of the parafascicular complex (CM-Pf) of the human thalamus in the neuronal mechanisms of selective attention. Neurosci Behav Physiol 36: 287-295. [Crossref]

78. Kezunovic N, Hyde J, Simon C, Urbano FJ, Williams DK, et al. (2012) Gamma band activity in the developing parafascicular nucleus. $J$ Neurophysiol107: 772-784 [Crossref]

79. Hyde J, Kezunovic N, Urbano FJ, Garcia-Rill E (2013) Visualization of fast calcium oscillations in the parafascicular nucleus. Pflugers Arch 465: 1327-1340. [Crossref]

80. Moruzzi G, Magoun HW (1949) Brain stem reticular formation and activation of the EEG. Electroencephalogr Clin Neurophysiol 1: 455-473. [Crossref]

81. Watson RT, Heilman KM, Miller BD, King FA (1974) Neglect after mesencephalic reticular formation lesions. Neurology 24: 294-298. [Crossref]

Copyright: $\odot 2016$ Garcia-Rill E. This is an open-access article distributed under the terms of the Creative Commons Attribution License, which permits unrestricted use, distribution, and reproduction in any medium, provided the original author and source are credited. 